\title{
Lethality of Commercial Whole-Muscle Beef Jerky Manufacturing Processes against Salmonella Serovars and Escherichia coli 0157:H7
}

\author{
DENNIS R. BUEGE, ${ }^{1}$ GINA SEARLS, ${ }^{1}$ AND STEVEN C. INGHAM ${ }^{2 *}$ \\ ${ }^{1}$ Department of Animal Sciences and ${ }^{2}$ Department of Food Science, University of Wisconsin, Madison, Wisconsin 53706, USA
}

MS 05-582: Received 15 November 2005/Accepted 27 April 2006

\begin{abstract}
Thermal processes used in making whole-muscle beef jerky include a drying step, which may result in enhanced pathogen thermotolerance and evaporative cooling that reduce process lethality. Several salmonellosis outbreaks have been associated with beef jerky. In this study, a standardized process was used to inoculate beef strips with five-strain cocktails of either Salmonella serovars or Escherichia coli $\mathrm{O} 157: \mathrm{H} 7$, to marinate the strips at $\mathrm{pH} 5.3$ for 22 to $24 \mathrm{~h}$ at $5^{\circ} \mathrm{C}$, and to convert the strips to jerky using various heating and drying regimes. Numbers of surviving organisms were determined during and after heating and drying. Salmonella reductions of $\geq 6.4 \mathrm{log} \mathrm{CFU}$ and similar reductions in E. coli O157:H7 were best achieved by ensuring that high wet-bulb temperatures were reached and maintained early in the process $\left(51.7\right.$ or $54.4^{\circ} \mathrm{C}$ for $60 \mathrm{~min}$, $57.2^{\circ} \mathrm{C}$ for $30 \mathrm{~min}$, or $60^{\circ} \mathrm{C}$ for $10 \mathrm{~min}$ ) followed by drying at $76.7^{\circ} \mathrm{C}$ (dry-bulb temperature). Processes with less lethality that reduced counts of both pathogens by $\geq 5.0 \log \mathrm{CFU}$ were (i) heating and drying at $76.7^{\circ} \mathrm{C}$ (dry bulb) within 90 min of beginning the process, (ii) heating for successive hourly intervals at $48.9,54.4,60$, and $76.7^{\circ} \mathrm{C}$ (dry bulb), and (iii) heating at $51.7^{\circ} \mathrm{C}$ (dry bulb) and then drying at $76.7^{\circ} \mathrm{C}$ (dry bulb), starting before the product water activity dropped below 0.86. In several trials, separate beef strips were inoculated with a commercial Pediococcus acidilactici starter culture as a potential surrogate for evaluating pathogen thermotolerance. The results of these trials suggested that this experimental approach may be useful for in-plant validation of process lethality.
\end{abstract}

The production of beef jerky from whole muscle or restructured ground meat differs from the production of other ready-to-eat meat products because heat processing is used to attain the desired dryness, texture, and shelf stability. However, this drying step may reduce the process lethality against pathogenic bacteria, and outbreaks of salmonellosis have been linked to the consumption of beef jerky (3). Previous research has suggested that sublethal drying conditions may lead to increased heat resistance in pathogens such as Salmonella serovars (5). Evaporative cooling that occurs during drying also may lessen the effective temperature to which pathogens are exposed. A possible decrease in lethality related to evaporative cooling on the surface of cooked beef was noted previously in studies of Salmonella survival during the cooking of beef $(1,6)$. Blankenship et al. (2) recommended introduction of steam into the oven when cooking beef roasts to ensure that adequate lethality against salmonellae was attained on the roast surface. Evaporative cooling also was noted as a factor contributing to insufficient thermal lethality in making the jerky associated with an outbreak of salmonellosis in New Mexico in 2003 (11). All of these factors have resulted in heightened scrutiny of the lethality of the heating and drying steps typically used during jerky processing.

U.S. Department of Agriculture (USDA) officials have issued a compliance guideline for jerky processors (14) that

\footnotetext{
* Author for correspondence. Tel: 608-265-4801; Fax: 608-262-6872;
}

E-mail: scingham@wisc.edu. stresses the importance of maintaining high humidity during thermal processing to ensure sufficient destruction of Salmonella and Escherichia coli O157:H7. However, processors have had difficulty either complying with USDA guidelines or developing and validating adequate alternative processes while maintaining desired characteristics in the finished product. Previously suggested techniques for ensuring adequate lethality included boiling beef strips in marinade prior to cooking and drying and heating beef jerky strips in an oven after drying $(7,9)$. Commercial processors have not widely adopted these methods, either because of perceived adverse effects on product sensory characteristics or because of economic or efficiency concerns. Development of validated heating and drying guidelines for processors of whole-muscle jerky has been further complicated by variables such as the thickness of the jerky strips, whether the strips have been marinated and if so the composition of the marinade and the marination conditions, the type of smokehouse or oven used for heating and/or drying, and the weather and altitude at the processing plant.

The USDA has suggested that a jerky-making process has sufficient lethality if it results in a 5-log reduction of Salmonella (12) and has stated that the lethality of nonthermal steps in jerky making, such as marination, can be counted toward meeting the overall process lethality requirement (4). Preexisting USDA guidelines for certain other beef products have specified a $6.5-\log$ reduction in Salmonella (13). The newer 5-log reduction standard resulted 
from a USDA draft risk assessment of the impact on the incidence of salmonellosis of different lethality standards for ready-to-eat meat and poultry products (16). In this risk assessment, researchers determined that a decrease in the pathogen standard from a $6.5-\log$ reduction to a 5-log reduction for products such as jerky, which does not usually support the growth of salmonellae, would have little effect on the incidence of salmonellosis.

The first objective of this study was to develop and validate sufficiently lethal processes for use by commercial jerky manufacturers in heating and drying of whole-muscle beef jerky. There are many variations in commercial beef jerky processing techniques. In working toward this objective, we used a common marination procedure and beef strip thickness (based on conversations with processors) and a standardized smokehouse loading procedure.

The second objective of this study was to develop a simple method that commercial processors of whole-muscle beef jerky could use to evaluate the lethality of new processes. Because in-plant challenge studies involving pathogenic bacteria are not recommended for commercial meat processing establishments for safety reasons and because laboratory-based challenge studies are neither practical nor affordable for most processors, we investigated the use of a commercially available Pediococcus acidilactici starter culture as a surrogate for evaluating the thermotolerance of strains of Salmonella serovars and E. coli O157:H7. The use of a nonpathogenic surrogate organism for evaluating thermal destruction of a pathogen has a long history in the food industry. For example, endospores of Clostridium sporogenes strain PA 3679 have been used frequently as a surrogate for endospores of the less heat tolerant but very dangerous Clostridium botulinum for establishing safe thermal processes for canned low-acid foods (10). Preliminary experiments in our laboratory have indicated that $P$. acidilactici is more thermotolerant than Salmonella serovars and E. coli $\mathrm{O} 157: \mathrm{H} 7$, and neither P. acidilactici nor the pathogens grew during the standardized jerky marination procedure. $P$. acidilactici is widely used in the meat industry, so its presence in a meat processing plant and, potentially, in products made in that plant would be acceptable to regulators.

\section{MATERIALS AND METHODS}

Preparation of inoculum. Five-strain cocktails of Salmonella serovars and E. coli $\mathrm{O} 157: \mathrm{H} 7$ were used to inoculate beef strips before jerky processing. E. coli O157:H7 strains ATCC 43894, ATCC 51657, and ATCC 51658 were clinical isolates and strain ATCC 43895 was originally isolated from ground beef implicated in an outbreak of foodborne illness; each of these strains was obtained from the American Type Culture Collection (Manassas, Va.). Strain USDA-FSIS-380-94 was originally from salami implicated in an illness outbreak and was obtained from the laboratory of Dr. John Luchansky (Food Research Institute, University of Wisconsin, Madison; this strain may now be obtained from the authors). The Salmonella serovars were all obtained from the laboratory of Dr. Eric Johnson (Food Research Institute). Salmonella Typhimurium S9 and Salmonella Heidelberg S13 were originally clinical isolates from the Wisconsin Laboratory of Hygiene, and Salmonella Enteritidis E40 was originally a chicken ovary isolate obtained from the New York Department of Health. The original sources of Salmonella Infantis S20 and Salmonella Hadar S21 are not known. To obtain a working culture, each strain was cultured twice successively (from a previously frozen culture) at $35^{\circ} \mathrm{C}$ for 18 to $24 \mathrm{~h}$ in brain heart infusion broth (BHIB; Difco, Becton Dickinson, Sparks, Md.), streaked to brain heart infusion agar (BHIA; Difco, Becton Dickinson), incubated at $35^{\circ} \mathrm{C}$ for 18 to $24 \mathrm{~h}$, examined for uniform colony morphology, and then stored at $5^{\circ} \mathrm{C}$. The jerky marinade used in our study had a $\mathrm{pH}$ (5.3) well above the minimum $\mathrm{pH}$ (4.7) for low-acid foods. Thus, cultures for inoculation were not intentionally acid adapted but instead were grown in BHIB, a medium containing only a small amount of glucose that could be metabolized to produce organic acids. To achieve stationary-phase cultures for inoculation, an isolated colony of each strain was transferred from its working culture plate to $9 \mathrm{ml}$ of BHIB and incubated at $35^{\circ} \mathrm{C}$ for $24 \mathrm{~h}$. To prepare a five-strain inoculum cocktail of Salmonella serovars or E. coli $\mathrm{O} 157: \mathrm{H7}$, the BHIB culture of each strain was combined into one sterile $50-\mathrm{ml}$ plastic centrifuge tube and centrifuged for $12 \mathrm{~min}$ at $5,000 \times g$. The supernatant in each tube was decanted, and the pellets were resuspended with approximately $20 \mathrm{ml}$ of Butterfield's phosphate diluent (BPD; Nelson Jameson, Marshfield, Wis.). A commercial $P$. acidilactici starter culture intended for making fermented meat products was evaluated in several trials as a surrogate for the pathogens. The starter culture (Formula 100, Trumark, Linden, N.J.) was stored at $-20^{\circ} \mathrm{C}$. Three different lots of this starter culture were tested during the study. Preliminary experiments revealed that $P$. acidilactici was considerably more thermotolerant than the Salmonella and E. coli O157:H7 strains used, so a lower $P$. acidilactici inoculum concentration was used. To prepare the $P$. acidilactici for inoculation of beef strips, $0.5 \mathrm{~g}$ of culture was added to $99 \mathrm{ml}$ of BPD, mixed well, and then diluted 100-fold in BPD.

Inoculation of beef strips. Frozen vacuum-packaged beef strips were obtained from a commercial jerky processor and thawed at $4{ }^{\circ} \mathrm{C}$ or under running tap water before inoculation. The individual beef strips ( 5 to $7 \mathrm{~mm}$ thick) were placed in a biosafety hood on aluminum foil that had been previously sanitized with $70 \%$ (vol/vol) ethanol. To inoculate each strip, $0.4 \mathrm{ml}$ of the undiluted pathogen cocktail or $0.4 \mathrm{ml}$ of the diluted starter culture was pipetted onto the product surface and distributed as evenly as possible with a sterile plastic spreader. Aluminum foil was placed over the strips in a tented manner to minimize the amount of drying during microbial attachment (30 min), after which strips were turned over and the inoculation and attachment process was repeated on the other side. For each trial, one group of 9 to 12 beef strips was inoculated with Salmonella, another group of 9 to 12 beef strips was inoculated with E. coli $\mathrm{O} 157: \mathrm{H7}$, and a third group of 4 to 6 uninoculated beef strips was used to monitor yield and water activity throughout thermal processing. In 20 trials (18 in a commercial smokehouse and 2 in a consumer-scale dehydrator oven), four additional strips were inoculated with $P$. acidilactici. Initial pathogen concentrations on inoculated beef strips were approximately $10^{8} \mathrm{CFU}$ per strip and initial $P$. acidilactici concentrations were 3.3 to $4.7 \log \mathrm{CFU}$ per strip.

Jerky processing. Each group of beef strips was tumbled manually in a closed zip-lock plastic bag for approximately 5 min in a spice marinade ( $\mathrm{pH} 5.3$ ) applied at $15 \%$ (wt/wt: $9.7 \%$ water and $5.3 \%$ dry ingredients) to obtain preprocessing concentrations of $2 \%$ sodium chloride (wt/wt), $2 \%$ sucrose (wt/wt), and $156 \mathrm{ppm}$ sodium nitrite (wt/wt) in the meat. Following marination, strips were held for 22 to $24 \mathrm{~h}$ at $5^{\circ} \mathrm{C}$. The next day, strips were arranged on racks placed in the center of a commercial one-truck smoke- 
TABLE 1. Summary of heating and drying processes used to make whole-muscle beef jerky

\begin{tabular}{|c|c|c|c|c|c|c|}
\hline \multirow{2}{*}{$\begin{array}{c}\text { Process } \\
\text { type }\end{array}$} & \multirow{2}{*}{\multicolumn{2}{|c|}{$\begin{array}{l}\text { Cumulative } \\
\text { time (min) }\end{array}$}} & \multicolumn{2}{|c|}{ Dry bulb } & \multicolumn{2}{|c|}{ Wet bulb } \\
\hline & & & Temp $\left({ }^{\circ} \mathrm{C}\right)$ & Time (min) & Temp $\left({ }^{\circ} \mathrm{C}\right)$ & $\% \mathrm{RH}^{a}$ \\
\hline \multirow[t]{7}{*}{$1-\mathrm{A}$} & & 15 & $62.8\left(145^{\circ} \mathrm{F}\right)$ & 15 & $\mathrm{NC}^{b}$ & \\
\hline & & 30 & $76.7\left(170^{\circ} \mathrm{F}\right)$ & 15 & $\mathrm{NC}$ & \\
\hline & Then & 90 & 76.7 & 60 & $51.7\left(125^{\circ} \mathrm{F}\right)$ & 27 \\
\hline & Or & 90 & 76.7 & 60 & $54.4\left(130^{\circ} \mathrm{F}\right)$ & 32 \\
\hline & Or & 60 & 76.7 & 30 & $57.2\left(135^{\circ} \mathrm{F}\right)$ & 37 \\
\hline & Or & 40 & 76.7 & 10 & $60\left(140^{\circ} \mathrm{F}\right)$ & 43 \\
\hline & Then & $>90$ & 76.7 & Variable $^{c}$ & $\mathrm{NC}$ & \\
\hline \multirow[t]{7}{*}{$1-B$} & & 15 & 62.8 & 15 & $\mathrm{NC}$ & \\
\hline & Then & 30 & $65.5\left(150^{\circ} \mathrm{F}\right)$ & 15 & $\mathrm{NC}$ & \\
\hline & & 90 & 65.5 & 60 & 54.4 & 56 \\
\hline & & $>90$ & 65.5 & Variable $^{c}$ & $\mathrm{NC}$ & \\
\hline & Or & 30 & $87.8\left(190^{\circ} \mathrm{F}\right)$ & 15 & $\mathrm{NC}$ & \\
\hline & & 90 & 87.8 & 60 & 54.4 & 19 \\
\hline & & $>90$ & 87.8 & Variable $^{c}$ & $\mathrm{NC}$ & \\
\hline 2 & & 15 & 62.8 & 15 & $\mathrm{NC}$ & \\
\hline & & $>15$ & 76.7 & Variable ${ }^{c}$ & $\mathrm{NC}$ & \\
\hline 3 & & 90 & 62.8 & 90 & $\mathrm{NC}$ & \\
\hline & & $>90$ & 76.7 & Variable $^{c}$ & $\mathrm{NC}$ & \\
\hline 4 & & Variable & 51.7 & Variable $^{d}$ & $\mathrm{NC}$ & \\
\hline & & Variable & 76.7 & Variable $^{c}$ & $\mathrm{NC}$ & \\
\hline 5 & & Variable & 60 & Variable $^{c}$ & $\mathrm{NC}$ & \\
\hline & Or & Variable & $71.1\left(160^{\circ} \mathrm{F}\right)$ & Variable ${ }^{c}$ & $\mathrm{NC}$ & \\
\hline & Or & Variable & $82.2\left(180^{\circ} \mathrm{F}\right)$ & Variable $^{c}$ & $\mathrm{NC}$ & \\
\hline 6 & & 60 & $48.9\left(120^{\circ} \mathrm{F}\right)$ & 60 & $\mathrm{NC}$ & \\
\hline & & 120 & 54.4 & 60 & $\mathrm{NC}$ & \\
\hline & & 180 & 60 & 60 & $\mathrm{NC}$ & \\
\hline 7 & & 60 & 48.9 & 60 & $\mathrm{NC}$ & \\
\hline & & 120 & 54.4 & 60 & $\mathrm{NC}$ & \\
\hline & & 180 & 60 & 60 & $\mathrm{NC}$ & \\
\hline & & 240 & 76.7 & 60 & $\mathrm{NC}$ & \\
\hline
\end{tabular}

${ }^{a}$ During the wet-bulb temperature spike, \% RH was calculated with a slide rule for wet-bulb and dry-bulb temperature settings.

${ }^{b} \mathrm{NC}$, not controlled.

${ }^{c}$ To targeted dryness of final product.

${ }^{d}$ To targeted water activity.

house (model TR2, Vortron, Beloit, Wis.) for processing. Pans of water were placed on the lowest rack in the smokehouse, and a low fan speed was used to simulate as much as possible a drying rate consistent with a smokehouse containing several racks filled with product. The smokehouse dry-bulb and wet-bulb temperatures were monitored with thermocouples (L 113-1055 P/M, ThermoWorks, Alpine, Utah) and a data logger (model 92000-00, Barnant Co., Barrington, Ill.). Percent relative humidity (RH) was calculated from the wet-bulb and dry-bulb temperatures with a slide rule (Alkar, Lodi, Wis.). In all trials, the product internal temperature was measured by inserting a thermocouple probe into the geometric center of a beef strip. Because insertion of the probe in this location is relatively difficult, an alternative product internal temperature was also obtained in the majority of the trials by tightly folding a beef strip once over a thermocouple probe. This temperature measurement method is easier, but initially it was unclear whether it could be considered an accurate substitute for the insertion method. Smoke was not applied to the beef strips during processing.
Several types of heating and drying processes were tested (Table 1). In type 1-A processes, the dry-bulb temperature controller was set at $62.8^{\circ} \mathrm{C}\left(145^{\circ} \mathrm{F}\right)$ for the first $15 \mathrm{~min}$ and then at $76.7^{\circ} \mathrm{C}$ $\left(170^{\circ} \mathrm{F}\right)$ for the next $15 \mathrm{~min}$, with no added humidity. This twostep increase in dry-bulb temperature was used to simulate the beginning stages of heating a full smokehouse of moist ambient-temperature beef strips. Next, humidity (steam or water) was introduced into the smokehouse via the wet-bulb temperature controller to obtain targeted increases in wet-bulb temperatures (wet-bulb spikes). The process lethality was determined for a series of trials conducted using early process wet-bulb spikes of $51.7^{\circ} \mathrm{C}\left(125^{\circ} \mathrm{F}\right)$ for $60 \mathrm{~min}$, $54.4^{\circ} \mathrm{C}\left(130^{\circ} \mathrm{F}\right)$ for $60 \mathrm{~min}, 57.2^{\circ} \mathrm{C}\left(135^{\circ} \mathrm{F}\right)$ for $30 \mathrm{~min}$, and $60^{\circ} \mathrm{C}$ $\left(140^{\circ} \mathrm{F}\right)$ for $10 \mathrm{~min}$. During these wet-bulb spikes, 27, 32, 37, and $43 \%$ RH, respectively, was obtained. Following completion of wetbulb spikes, no further humidity was introduced into the smokehouse chamber, and the product was further dried at a dry-bulb temperature of $76.7^{\circ} \mathrm{C}$. To investigate the possible protective or lethal effects of marinade ingredients, a selected type 1 process $(32 \%$ $\mathrm{RH}$ for $60 \mathrm{~min}$ ) was used for products that were marinated either 
in water alone (9.7\% initial product weight gain) or in the dry ingredients alone (5.3\% initial product weight gain). In four trials, a type 1-B process was used (wet-bulb spike of $54.4^{\circ} \mathrm{C}$ for $60 \mathrm{~min}$ ) in which the dry-bulb temperature was held at either $65.5^{\circ} \mathrm{C}\left(150^{\circ} \mathrm{F}\right)$ or $87.8^{\circ} \mathrm{C}\left(190^{\circ} \mathrm{F}\right)$ throughout a 15 -min equilibration period before the wet-bulb spike, during the wet-bulb spike (56 and 19\% RH, respectively), and during final drying. Type 2 and type 3 processes involved rapid (15 $\mathrm{min}$ ) and slow $(90 \mathrm{~min})$, respectively, increases in dry-bulb temperature to $76.7^{\circ} \mathrm{C}$ followed by final drying at a dry-bulb temperature of $76.7^{\circ} \mathrm{C}$. In type 4 processes, the dry-bulb temperature was held constant at $51.7^{\circ} \mathrm{C}$ until a desired approximate water activity in the jerky was attained, whereupon the dry-bulb temperature was increased to $76.7^{\circ} \mathrm{C}$ for final drying (no humidity added during the process). In type 5 processes, the dry-bulb temperature was held constant at $60^{\circ} \mathrm{C}, 71.1^{\circ} \mathrm{C}\left(160^{\circ} \mathrm{F}\right)$, or $82.2^{\circ} \mathrm{C}$ $\left(180^{\circ} \mathrm{F}\right)$, and no attempt was made to control wet-bulb temperature. Type 6 and type 7 processes both involved sequential 1-h exposures to dry-bulb temperatures of $48.9^{\circ} \mathrm{C}\left(120^{\circ} \mathrm{F}\right), 54.4$, and $60^{\circ} \mathrm{C}$; in the type 7 process, beef strips were exposed for an additional hour to a dry-bulb temperature of $76.7^{\circ} \mathrm{C}$.

A consumer-scale dehydrator oven (Pragotrade model TS160, Cabela's, Sidney, Nebr.) was used for additional trials testing the relationship between thermally induced death of $P$. acidilactici and inoculated pathogens for a consumer-type process. Inoculated and uninoculated beef strips were placed on two racks in the oven, two large (15-cm diameter) petri dishes containing water were placed on the floor of the oven, and the dry-bulb temperature was set at either 60 or $70.1^{\circ} \mathrm{C}$.

These trials were conducted to compare pathogen and P. acidilactici survival over a broad range of conditions. In all trials, uninoculated strips were evaluated at the intermediate sampling point for water activity (measured on site with an AquaLab Series 3TE water activity meter; Decagon Devices, Inc., Pullman, Wash.), and additional uninoculated finished beef jerky strips were sent to a commercial testing laboratory for $\mathrm{pH}$, water activity, percent water (forced air oven method, AOAC 950.46Bb, AOAC International, Gaithersburg, Md.), percent protein (Kjeldahl method, AOAC 991.20.I, AOAC International), and percent salt (potentiometric method, AOAC 980.25, AOAC International). From these analyses, the moisture:protein ratio (MPR) and the percent water-phase salt values were calculated.

Enumeration of inoculum organisms. The numbers of Salmonella and E. coli $\mathrm{O} 157: \mathrm{H} 7$ cells on beef strips were determined prior to marination in all trials and after marination in 21 trials. Additional samples of unfinished but heated jerky were obtained after the early process wet-bulb temperature spike in the smokehouse (process type 1), when unfinished jerky water activity was 0.92 to 0.97 (process types $2,3,6$, and 7), after initial heating at $51.7^{\circ} \mathrm{C}$ in type 4 processes (when jerky water activity was 0.72 to 0.96 , depending on the trial), or after 60 or 90 min of constant dry-bulb-temperature heating in type 5 processes. Final samples were collected either when the jerky water activity fell to $\leq 0.90$ (process types 1, 2, 3, 5, 6, and 7) or 60 to $120 \mathrm{~min}$ after the previous sampling in type 4 processes. A sample consisted of one beef strip, and three samples were analyzed for pathogen concentrations at each sampling time. In several trials, two strips each were analyzed for starter culture concentrations after inoculation and at the end of drying.

Each sample was placed in a Whirl-Pak filter bag (Nasco, Fort Atkinson, Wis.), BPD (99 ml) was added, and the bag contents were stomached for $2 \mathrm{~min}$ at medium speed (Stomacher 400 Circulator lab blender, Seward, Worthington, UK). On rare occasions when the strip length or shape prevented use of the stom- acher, samples were manually massaged for $1 \mathrm{~min}$ and shaken for $1 \mathrm{~min}$. This initial dilution was arbitrarily defined as $10^{-1}$. Serial decimal dilutions were made in BPD as needed. From the initial dilution, $1.0 \mathrm{ml}$ was distributed for spread plating among three plates of BHIA. From the original dilution and each subsequent dilution, $0.1 \mathrm{ml}$ was spread on one BHIA plate per dilution. Plates were incubated at $35^{\circ} \mathrm{C}$ for $1 \mathrm{~h}$ to allow for repair of injured cells, and the cultures were then overlaid with MacConkey sorbitol agar (Difco, Becton Dickinson), xylose lysine deoxycholate agar (Difco, Becton Dickinson), or modified Enterococcus agar (Difco, Becton Dickinson) for selective and differential enumeration of $E$. coli O157:H7, Salmonella serovars, and P. acidilactici, respectively. Each overlay medium was chosen for ease in clearly recognizing presumptive colonies. After 20 to 24 h (E. coli O157: H7, Salmonella serovars) or $72 \mathrm{~h}$ ( $P$. acidilactici) of incubation at $35^{\circ} \mathrm{C}$, plates were examined for typical colonies. For each sampling time, one presumptive colony each of E. coli O157:H7 and Salmonella was transferred to BHIA, incubated at $35^{\circ} \mathrm{C}$ for 20 to $24 \mathrm{~h}$, and then tested to confirm colony identity. A single plate containing presumptive $P$. acidilactici colonies was retained for confirmation tests at each sampling time. Confirmation tests for the presumptive pathogens were Gram reaction, cellular morphology, oxidase activity, and biochemical characteristics (API 20E kit, bioMérieux, Hazelwood, Mo.) with an additional O157 latex agglutination test (Oxoid, Ogdensburg, N.Y.) to confirm E. coli $\mathrm{O} 157: \mathrm{H} 7$ isolates. Presumptive $P$. acidilactici colonies were evaluated for Gram reaction, cellular morphology, and catalase activity. The count (log CFU) for a given inoculum organism was calculated for each sample, and mean counts were calculated for each sampling time. A value of $9 \mathrm{CFU}$ (0.95 log CFU) was assigned when no colonies were present on the least dilute plating (1 CFU below the detection limit of $10 \mathrm{CFU}$ ).

\section{RESULTS AND DISCUSSION}

Finished jerky made in the present study had a $\mathrm{pH}$ of 5.6 to $6.1 ; 22$ of 30 samples had a $\mathrm{pH}$ of 5.7 to 5.9. The water activity, MPR, and percent water-phase salt varied widely, which was expected given the range of heating and drying conditions evaluated. In many trials in which sufficient lethality was achieved, the MPR of the jerky at the final sampling time was too high to meet the USDA MPR labeling standard of $\leq 0.75$ (15). However, processors using the same heating and drying processes could simply extend the drying period to obtain the mandated MPR. This extended drying would have no adverse effect on lethality and might, in some situations, increase it.

In 21 trials, pathogen numbers were determined following the 22- to 24-h refrigerated marination step. Salmonella and E. coli $\mathrm{O} 157: \mathrm{H} 7$ counts fell by 0.04 to 0.43 and 0.04 to $0.34 \log \mathrm{CFU}$, respectively. We concluded that this marination step contributed little to lethality, and we discontinued postmarination sampling.

As shown for a typical type 1 process (Fig. 1), the smokehouse wet-bulb temperature was consistently well below the dry-bulb temperature. Product internal temperature was always similar to the wet-bulb temperature early in the process and could effectively serve as an estimate of wetbulb temperature until later in the process. However, some time during the process evaporative cooling of the strips diminished and the product internal temperature rose toward the dry-bulb temperature. Throughout the jerky heat- 


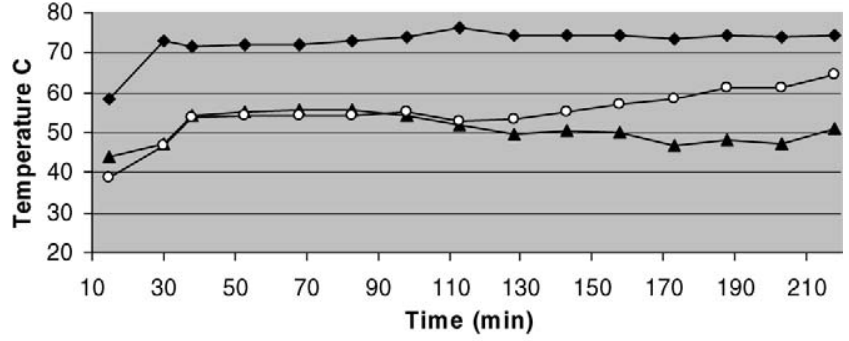

- Dry-Bulb $\_$Wet-Bulb $\multimap-$ - Product-Internal

FIGURE 1. Wet-bulb, dry-bulb, and product internal temperatures during the manufacture of whole-muscle beef jerky using a type 1-A process with a $54.4^{\circ} \mathrm{C}\left(130^{\circ} \mathrm{F}\right) 60$-min wet-bulb temperature spike.

ing and drying process, product internal temperature was always close to (within $1^{\circ} \mathrm{C}$ of) or higher than the chamber wet-bulb temperature. Thus, maintaining the chamber wetbulb temperature (and thereby the product temperature) high enough to cause pathogen destruction (ca. $51.7^{\circ} \mathrm{C}$ or higher) can strongly influence process lethality. Early in the heating and drying process, the alternative product internal temperature (measured with a jerky strip folded over the thermocouple) was often lower than the actual product internal temperature because the applied heat had to pass through twice the thickness of meat in the folded strip. Later in the process, the alternative product internal temperature rose above the actual product internal temperature, presumably because the greater meat thickness with the folded strip diminished evaporative cooling near the thermocouple. By the end of the process, when little evaporative cooling was occurring, the two temperatures were the same. The divergence of the two temperatures by a variable amount during much of the process calls into question the practice of using the alternative product internal temperature method for overall process control or evaluation.

Previous research has established that sublethal drying can make pathogens such as Salmonella serovars more resistant to heat (5). This phenomenon was likewise observed in several early jerky-making trials (data not shown). Therefore, several early process wet-bulb temperature spikes were applied to determine the extent of high-humidity heating conditions necessary to achieve desired lethality while maintaining product quality (Table 2). During the 27 , 32,37 , and $43 \% \mathrm{RH}$ processes with concurrent $76.7^{\circ} \mathrm{C}$ drybulb temperature, the product internal temperature was generally similar to the wet-bulb temperature. However, during

TABLE 2. Process lethality against Salmonella serovars (S) and Escherichia coli O157:H7 (EC) during type 1-A and type 1-B processing (wet-bulb temperature spike followed by postspike drying period) of whole-muscle beef jerky

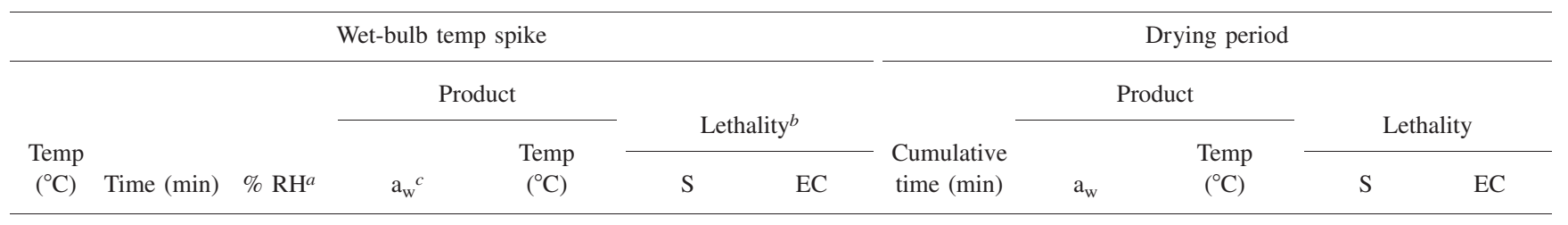

Type 1-A (strips marinated with water and dry ingredients, dry-bulb temp at $76.7^{\circ} \mathrm{C}$ during wet-bulb spike)

\begin{tabular}{|c|c|c|c|c|c|c|c|c|c|c|c|}
\hline 51.7 & 60 & 27 & 0.87 & 60.5 & 5.6 & 5.6 & 120 & 0.81 & 70.0 & 6.5 & 6.7 \\
\hline 51.7 & 60 & 27 & 0.89 & 56.1 & 5.2 & 3.8 & 120 & 0.78 & 65.0 & 6.4 & 7.1 \\
\hline 54.4 & 60 & 32 & 0.93 & 54.4 & 3.2 & 2.0 & 180 & 0.88 & 63.9 & 6.9 & 7.1 \\
\hline 54.4 & 60 & 32 & 0.92 & 55.0 & 3.9 & 2.1 & 180 & 0.87 & 64.4 & 6.9 & 7.0 \\
\hline 57.2 & 30 & 37 & ND & 58.3 & 6.4 & 2.7 & 150 & 0.86 & 63.9 & 7.0 & 7.1 \\
\hline 57.2 & 30 & 37 & 0.93 & 57.8 & 5.3 & 3.1 & 120 & 0.90 & 66.1 & 7.0 & 7.1 \\
\hline 60 & 10 & 43 & 0.96 & 58.9 & 6.2 & 3.8 & 130 & 0.90 & 67.8 & 7.0 & 7.2 \\
\hline 60 & 10 & 43 & 0.96 & 60.0 & 6.7 & 2.2 & 130 & 0.84 & 62.8 & 6.8 & 7.0 \\
\hline
\end{tabular}

Type 1-B (dry-bulb temp at $65.5^{\circ} \mathrm{C}$ during wet-bulb spike)

\begin{tabular}{|c|c|c|c|c|c|c|c|c|c|c|}
\hline 54.4 & 60 & 56 & 0.95 & 55.6 & 4.9 & 3.2 & 150 & 0.85 & 57.2 & 6.7 \\
\hline 54.4 & 60 & 56 & 0.97 & 55.0 & 5.0 & 3.6 & 210 & 0.91 & 57.8 & 6.9 \\
\hline
\end{tabular}

Type 1-B (dry-bulb temp at $87.8^{\circ} \mathrm{C}$ during wet-bulb spike)

$\begin{array}{rrrrrrrrrrrr}54.4 & 60 & 19 & 0.93 & 66.7 & 6.7 & 7.3 & 90 & 0.89 & 71.1 & 7.0 & 7.4 \\ 54.4 & 60 & 19 & 0.95 & 65.0 & 6.5 & 6.9 & 105 & 0.89 & 73.9 & 7.2 & 7.1\end{array}$

Type 1-A (strips marinated in water only, dry-bulb temp at $76.7^{\circ} \mathrm{C}$ during wet-bulb spike)

\begin{tabular}{|c|c|c|c|c|c|c|c|c|c|c|}
\hline 54.4 & 60 & 32 & 0.98 & 55.6 & 5.6 & 4.9 & 120 & 0.94 & 63.9 & 6.6 \\
\hline 54.4 & 60 & 32 & 0.99 & 55.6 & 5.4 & 4.5 & 120 & 0.96 & 64.4 & 6.1 \\
\hline
\end{tabular}

Type 1-A (strips marinated with dry ingredients only, dry-bulb temp at $76.7^{\circ} \mathrm{C}$ during wet-bulb spike)

\begin{tabular}{|c|c|c|c|c|c|c|c|c|c|c|}
\hline 54.4 & 60 & 32 & 0.95 & 58.9 & 5.9 & 3.9 & 150 & 0.87 & 66.7 & 7.1 \\
\hline 54.4 & 60 & 32 & 0.93 & 58.9 & 5.6 & 6.9 & 120 & 0.68 & 68.3 & 6.6 \\
\hline
\end{tabular}

${ }^{a}$ During the wet-bulb temperature spike, $\%$ RH was calculated with a slide rule for wet-bulb and dry-bulb temperature settings.

${ }^{b}$ Reduction in log CFU per sample relative to initial pathogen load before marination. Values are mean $(n=3)$ reduction in log CFU for a single trial.

${ }^{c}$ Water activity, $n=1$ for each trial. ND, not determined. 


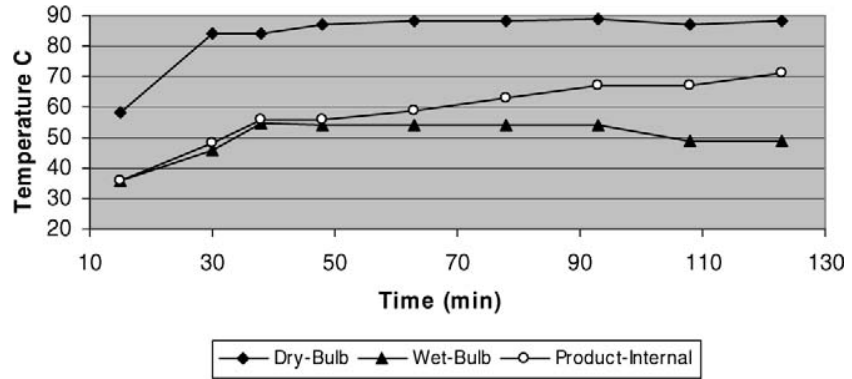

FIGURE 2. Wet-bulb, dry-bulb, and product internal temperatures during the manufacture of whole-muscle beef jerky using a type 1-B process with a dry-bulb temperature setting of $87.8^{\circ} \mathrm{C}$ $\left(190^{\circ} \mathrm{F}\right)$.

the $19 \% \mathrm{RH}$ process with a concurrent $87.8^{\circ} \mathrm{C}$ dry-bulb temperature, the product internal temperature rose faster than it did during 27 to $43 \% \mathrm{RH}$ processes conducted at $76.7^{\circ} \mathrm{C}$ dry-bulb temperature, and the product internal temperature reached at least $5^{\circ} \mathrm{C}$ higher (Fig. 2) than it did in a $32 \% \mathrm{RH}$ type 1 -A process (Fig. 1). This more rapid increase in product temperature resulted from faster jerky drying at the lower percent $\mathrm{RH}$.

The USDA currently states that a jerky-making process has sufficient lethality when it results in a 5-log reduction of Salmonella serovars. However, USDA guidelines for certain other beef products specify a 6.5-log reduction in Salmonella serovars (13). All tested type 1 processes resulted in $\geq 6.4-\log$ reduction in both pathogens by the final sampling time (Table 2). Three type 1 processes achieved $\geq 5$.2$\log$ reduction in Salmonella serovars but caused smaller decreases in E. coli O157:H7 numbers at the end of the wet-bulb temperature spike (Table 2). These treatments were $27 \% \mathrm{RH}$ for $60 \mathrm{~min}, 37 \% \mathrm{RH}$ for $30 \mathrm{~min}$, and $43 \%$ $\mathrm{RH}$ for $10 \mathrm{~min}$. However, $\geq 6.4-\log$ reduction of both $\mathrm{Sal}$ monella serovars and E. coli $\mathrm{O} 157: \mathrm{H} 7$ was achieved by the final sampling time with these processes. One type 1 process did not result in a $>5.0-\log$ reduction in either pathogen by the end of the web-bulb spike, but subsequent drying resulted in sufficient overall lethality. This wet-bulb spike (32\% RH for $60 \mathrm{~min}$ ) resulted in decreases of 3.2 to 3.9 and 2.0 to $2.1 \log$ CFU for Salmonella serovars and $E$. coli $\mathrm{O} 157: \mathrm{H} 7$, respectively, but by the postdrying sampling time, $\geq 6.9-\log$ reductions had occurred for both pathogen types. The overall effectiveness of these type 1 processes was attributed to the fact that product temperature was controllable via control of the wet-bulb temperature and increased rapidly to levels at which pathogens were killed while the beef strips were still moist enough to achieve high lethality. The duration of the wet-bulb temperature spike was generally shorter than the corresponding times for cooking beef listed for the same wet-bulb temperatures by the USDA (13): $112 \mathrm{~min}$ at $54.4^{\circ} \mathrm{C}, 36 \mathrm{~min}$ at $57.2^{\circ} \mathrm{C}$, and $12 \mathrm{~min}$ at $60^{\circ} \mathrm{C}$. Times used in the present study were 60 , 30 , and $10 \mathrm{~min}$, respectively.

The dry-bulb temperature during a type 1 process had a major effect on process lethality. After $60 \mathrm{~min}$ at $56 \%$ $\mathrm{RH}$ with a concurrent dry-bulb temperature of $65.5^{\circ} \mathrm{C}, \mathrm{Sal}$ monella serovar populations fell by 4.9 to $5.0 \log \mathrm{CFU}$, but
E. coli $\mathrm{O} 157: \mathrm{H} 7$ numbers fell by only 3.2 to $3.6 \log \mathrm{CFU}$ (Table 2). Subsequent drying at $65.5^{\circ} \mathrm{C}$, however, resulted in overall $\geq 6.7 \log$ CFU reductions in both pathogens by the final sampling time. These final sample results were not noticeably different than results obtained for $32 \% \mathrm{RH}$ for $60 \mathrm{~min}$ and a concurrent dry-bulb temperature of $76.7^{\circ} \mathrm{C}$, perhaps because pathogen populations in both situations had fallen below the detection limit by the final sampling time. When the concurrent dry-bulb temperature was increased to $87.8^{\circ} \mathrm{C}$ and the strips were exposed to $19 \% \mathrm{RH}$ for $60 \mathrm{~min}$, populations of both pathogens fell by $\geq 6.5 \mathrm{log}$ CFU by the end of the wet-bulb temperature spike (Table 2).

Although USDA guidelines (14) recommend 90\% RH during the early heating period in jerky processing, they also state that such a high humidity may not be necessary if alternative procedures are validated. The type 1-A processes used in this study with a dry-bulb temperature of $76.7^{\circ} \mathrm{C}$ and 27 to $43 \% \mathrm{RH}$ achieved $\geq 6.4 \log \mathrm{CFU}$ reduction for Salmonella serovars and E. coli O157:H7 when followed by drying at $76.7^{\circ} \mathrm{C}$. With a $5-\log$ pathogen reduction target for jerky processing lethality, processors using the type 1 process conditions employed in this study (reaching $76.7^{\circ} \mathrm{C}$ dry-bulb temperature within $30 \mathrm{~min}$ and maintaining this temperature throughout processing) could employ any of the early process percent $\mathrm{RH}$ values listed in Table 1 followed by drying at $76.7^{\circ} \mathrm{C}$ as scientifically validated processes for making safe whole-muscle beef jerky.

Separate trials were conducted with a type 1-A process to evaluate the relative importance of the marinade components for achieving desired process lethality. Omission of either water or dry ingredients from the marinade led to somewhat greater pathogen reductions after a wet-bulb temperature spike at $32 \% \mathrm{RH}$ for $60 \mathrm{~min}$ (Table 2) but to comparable lethality as determined at the final sampling time. We concluded that inclusion of either water or dry marinade ingredients, at the levels used in this study, was not a critical factor in attaining desired process lethality.

As expected, the type 2 process involving a rapid (15 min) increase in dry-bulb temperature to $76.7^{\circ} \mathrm{C}$ resulted in slightly greater pathogen destruction at $60 \mathrm{~min}$ than did the type 3 process at 90 min (Table 3 ). In the type 3 process, the dry-bulb temperature did not reach $76.7^{\circ} \mathrm{C}$ until after $90 \mathrm{~min}$. However, both of these processes resulted in pathogen reductions exceeding $5.0 \log$ CFU by the final sampling time.

An alternative approach that some processors may elect to use is to initially heat beef strips at the relatively moderate dry-bulb temperature of $51.7^{\circ} \mathrm{C}$ for a short time followed by heating and drying of the strips at a the relatively high dry-bulb temperature of $76.7^{\circ} \mathrm{C}$. The rationale for this approach (type 4 process) is that the short initial heating period imparts desirable product characteristics without increasing pathogen thermotolerance via sublethal stress. As seen in Table 4, the lethality of a type 4 process depends on beginning the high-temperature drying when the product water activity is still relatively high. When drying was begun at a product water activity of 0.72 or 0.81 , the reduc- 
TABLE 3. Process lethality against Salmonella serovars (S) and Escherichia coli O157:H7 (EC) during type 2, 3, 6, and 7 processes for heating and drying of whole-muscle beef jerky

\begin{tabular}{|c|c|c|c|c|c|c|c|c|c|c|c|c|}
\hline \multirow{4}{*}{$\begin{array}{l}\text { Pro- } \\
\text { cess- } \\
\text { type }\end{array}$} & \multicolumn{7}{|c|}{ Unfinished heated jerky } & \multicolumn{5}{|c|}{ Final dried jerky } \\
\hline & \multirow{2}{*}{\multicolumn{2}{|c|}{$\% \mathrm{RH}^{b}$}} & \multirow{3}{*}{$\begin{array}{c}\text { Sampling } \\
\text { time } \\
(\min )\end{array}$} & \multirow{2}{*}{\multicolumn{2}{|c|}{ Product }} & \multirow{2}{*}{\multicolumn{2}{|c|}{ Lethality ${ }^{c}$}} & \multirow{3}{*}{$\begin{array}{l}\text { Sampling } \\
\text { time } \\
(\min )\end{array}$} & \multicolumn{2}{|c|}{ Product } & \multirow{2}{*}{\multicolumn{2}{|c|}{ Lethality }} \\
\hline & & & & & & & & & & & & \\
\hline & Start & End & & $\mathrm{a}_{\mathrm{w}}{ }^{d}$ & $\left({ }^{\circ} \mathrm{C}\right)$ & S & $\mathrm{EC}$ & & $a_{w}$ & $\left({ }^{\circ} \mathrm{C}\right)$ & S & EC \\
\hline \multirow[t]{2}{*}{2} & 31 & 17 & 60 & 0.95 & 48.9 & 3.3 & 2.7 & 120 & 0.86 & 62.8 & 6.1 & 5.6 \\
\hline & 27 & 21 & 60 & 0.96 & 52.8 & 2.6 & 1.8 & 120 & 0.91 & 67.8 & 6.4 & 6.4 \\
\hline 3 & 41 & 21 & 90 & 0.97 & 46.7 & 2.0 & 1.5 & 180 & 0.87 & 67.8 & 5.5 & 5.6 \\
\hline 6 & 41 & 24 & 120 & 0.92 & 40.5 & 1.6 & 1.7 & 180 & 0.84 & 51.1 & 2.9 & 2.7 \\
\hline 7 & 43 & 15 & 180 & 0.94 & 49.4 & 3.5 & 2.5 & 240 & 0.89 & 67.2 & 6.0 & 5.6 \\
\hline
\end{tabular}

a 2 , fast come-up $\left(15 \mathrm{~min}\right.$ to reach dry-bulb temperature of $76.7^{\circ} \mathrm{C}\left(170^{\circ} \mathrm{F}\right)$, followed by drying at $\left.76.7^{\circ} \mathrm{C}\right)$; 3 , slow come-up $(90$ min to reach dry-bulb temperature of $76.7^{\circ} \mathrm{C}$, followed by drying at $\left.76.7^{\circ} \mathrm{C}\right) ; 6,1 \mathrm{~h}$ each at dry-bulb temperatures of $48.9,54.4$, and $60^{\circ} \mathrm{C}$ $\left(120,130\right.$, and $\left.140^{\circ} \mathrm{F}\right) ; 7,1 \mathrm{~h}$ each at dry-bulb temperatures of $48.9,54.4,60$, and $76.7^{\circ} \mathrm{C}$. No humidity was added to the chamber during processing.

${ }^{b}$ Percent relative humidity (initial value and final value). Values were calculated with a slide rule for wet-bulb and dry-bulb temperatures. ${ }^{c}$ Values are mean $(n=3)$ reductions in $\log \mathrm{CFU}$ for a single trial.

${ }^{d}$ Water activity $(n=1)$.

tion in Salmonella serovars was $4.7 \log$ CFU. However, the reduction in E. coli $\mathrm{O} 157: \mathrm{H} 7$ in these trials was $5.4 \mathrm{log}$ $\mathrm{CFU}$. When drying was begun at a product water activity of $0.86,0.87,0.95$, or 0.96 , the reduction in both pathogens was 4.9 to $6.7 \log \mathrm{CFU}$. The type 4 process clearly provided less of a safety margin than did the type 1 processes.

Heating whole-muscle beef strips at a constant drybulb temperature of either 60 or $71.1^{\circ} \mathrm{C}$ without the addition of humidity (type 5 processes) did not achieve even a 5$\log$ pathogen reduction, although product was dried to a water activity typical of commercial beef jerky (Table 5). These processes resulted in decreases in Salmonella serovars and E. coli $\mathrm{O} 157: \mathrm{H} 7$ of 3.8 to 4.7 and 3.9 to $4.0 \mathrm{log}$ $\mathrm{CFU}$, respectively. However, heating at a constant dry-bulb temperature of $82.2^{\circ} \mathrm{C}$ resulted in a reduction of just more than $5 \log \mathrm{CFU}$ for both pathogens. The cause of the lower lethality in type 5 processes can be inferred from Figure 3 $\left(60^{\circ} \mathrm{C}\right.$ process). The wet-bulb temperature and product internal temperature remained at sublethal levels for long periods of time, allowing pathogen survival during drying.

The type 6 process, with a slow increase in dry-bulb temperature to a maximum of $60^{\circ} \mathrm{C}$, resulted in a $\leq 3 \log$ $\mathrm{CFU}$ reduction in pathogens. In contrast, the type 7 process, which had a final 1-h exposure to a dry-bulb temperature of $76.7^{\circ} \mathrm{C}$, resulted in $>5 \log \mathrm{CFU}$ decreases in pathogen numbers (Table 3 ).

The $P$. acidilactici tested in 20 trials as a pathogen surrogate seems to have survived the jerky-making process better than did either of the tested pathogens (Table 6). In several trials, no surviving cells were detected, and thus an exact determination of the log reduction was not possible. However, when surviving cells were detected, the reduction

TABLE 4. Process lethality against Salmonella serovars $(S)$ and Escherichia coli O157:H7 (EC) during the type 4 process for heating and drying whole-muscle beef jerky ${ }^{a}$

\begin{tabular}{|c|c|c|c|c|c|c|c|c|c|c|c|}
\hline \multicolumn{7}{|c|}{ Unfinished heated jerky } & \multicolumn{5}{|c|}{ Final dried jerky } \\
\hline \multicolumn{2}{|c|}{$\% \mathrm{RH}^{b}$} & \multirow{2}{*}{$\begin{array}{l}\text { Sampling } \\
\text { time } \\
(\min )\end{array}$} & & & \multicolumn{2}{|c|}{ Lethality $^{c}$} & \multirow{2}{*}{$\begin{array}{c}\text { Sampling } \\
\text { time } \\
\text { (min) }\end{array}$} & & & \multicolumn{2}{|c|}{ Lethality } \\
\hline Start & End & & $\mathrm{a}_{\mathrm{w}}{ }^{d}$ & $\left({ }^{\circ} \mathrm{C}\right)$ & S & $\mathrm{EC}$ & & $a_{w}$ & $\left({ }^{\circ} \mathrm{C}\right)$ & S & $\mathrm{EC}$ \\
\hline $\mathrm{ND}^{e}$ & ND & 240 & 0.72 & 47.2 & 3.3 & 3.1 & 300 & 0.65 & 74.4 & 4.7 & 5.4 \\
\hline ND & ND & 270 & 0.87 & 45.6 & 4.3 & 2.9 & 330 & 0.82 & 71.7 & 5.8 & 6.7 \\
\hline 33 & 38 & 120 & 0.95 & 37.8 & 1.8 & 1.7 & 240 & 0.83 & 67.8 & 4.9 & 5.7 \\
\hline 35 & 38 & 120 & 0.96 & 38.9 & 2.1 & 1.9 & 225 & 0.82 & 70.0 & 5.6 & 5.9 \\
\hline
\end{tabular}

${ }^{a}$ Meat strips were heated at a constant dry-bulb temperature of $51.7^{\circ} \mathrm{C}\left(125^{\circ} \mathrm{F}\right)$ to attain the desired water activity and then dried at $76.7^{\circ} \mathrm{C}\left(170^{\circ} \mathrm{F}\right)$. No humidity was added to the chamber during processing.

${ }^{b}$ Percent relative humidity (initial value and final value). Values were calculated with a slide rule for wet-bulb and dry-bulb temperatures.

${ }^{c}$ Reduction in log CFU per sample relative to initial pathogen load before marination. Values are mean $(n=3)$ reduction in log CFU for a single trial.

$d$ Water activity $(n=1)$.

${ }^{e} \mathrm{ND}$, not determined. 
TABLE 5. Process lethality against Salmonella serovars $(S)$ and Escherichia coli O157:H7 (EC) during the type 5 process of heating and drying of whole-muscle beef jerky ${ }^{a}$

\begin{tabular}{|c|c|c|c|c|c|c|c|c|c|c|c|c|}
\hline \multicolumn{8}{|c|}{ Unfinished heated jerky } & \multicolumn{5}{|c|}{ Final dried jerky } \\
\hline \multirow{2}{*}{$\begin{array}{l}\text { Dry- } \\
\text { bulb } \\
\text { temp } \\
\left({ }^{\circ} \mathrm{C}\right)\end{array}$} & \multicolumn{2}{|c|}{$\% \mathrm{RH}^{b}$} & \multirow{2}{*}{$\begin{array}{c}\text { Sampling } \\
\text { time } \\
(\mathrm{min})\end{array}$} & & & \multicolumn{2}{|c|}{ Lethality ${ }^{c}$} & \multirow{2}{*}{$\begin{array}{c}\text { Sampling } \\
\text { time } \\
\text { (min) }\end{array}$} & & & \multicolumn{2}{|c|}{ Lethality } \\
\hline & Start & End & & $\mathrm{a}_{\mathrm{w}}{ }^{d}$ & $\left({ }^{\circ} \mathrm{C}\right)$ & $\mathrm{S}$ & EC & & $a_{w}$ & $\left({ }^{\circ} \mathrm{C}\right)$ & $\mathrm{S}$ & $\mathrm{EC}$ \\
\hline 60.0 & 32 & 24 & 90 & 0.73 & 46.7 & 4.3 & 3.8 & 120 & 0.64 & 53.9 & 4.2 & 3.9 \\
\hline 82.2 & 29 & 15 & 60 & 0.72 & 64.4 & 5.2 & 4.6 & 75 & 0.65 & 72.2 & 5.1 & 5.6 \\
\hline
\end{tabular}

${ }^{a}$ Meat strips were heated at a constant dry-bulb temperature of $60,71.1$, or $82.2^{\circ} \mathrm{C}\left(140,160\right.$, or $\left.180^{\circ} \mathrm{F}\right)$. No humidity was added to the chamber during processing.

${ }^{b}$ Percent relative humidity (initial value and final value). Values were calculated with a slide rule for wet-bulb and dry-bulb temperatures.

${ }^{c}$ Reduction in log CFU per sample relative to initial pathogen load before marination. Values are mean $(n=3)$ reduction in log CFU for a single trial.

${ }^{d}$ Water activity $(n=1)$.

in $\log$ CFU was always less than that for the pathogens. When the starter culture population was reduced by at least $3.0 \log \mathrm{CFU}$ or no surviving cells were detected (a log CFU reduction of at least 2.3 to $3.4 \log \mathrm{CFU} ; 13$ trials), the corresponding pathogen reductions were at least $5.0 \mathrm{log}$ CFU in 12 of the trials. In the one exception, the E. coli O157:H7 population decreased by $5.4 \log \mathrm{CFU}$ and the population of Salmonella serovars was reduced by $4.7 \mathrm{log}$ CFU. In contrast, when surviving $P$. acidilactici cells were detected and the population was reduced by $<3.0 \log \mathrm{CFU}$ (seven trials), pathogen populations were much less likely to decrease by at least $5.0 \log$ CFU. Counts of Salmonella serovars and E. coli O157:H7 decreased by $<5.0 \log \mathrm{CFU}$ in four and three of these trials, respectively. Thus, $P$. acidilactici could be useful as a thermal processing indicator for processors validating their whole-muscle beef jerky processes. However, further studies are necessary to determine the appropriate inoculum concentration and the critical reduction in P. acidilactici count that must be achieved. More specific enumeration procedures for $P$. acidilactici may be necessary because contamination of commercial pediococcal starter cultures with streptococci has been reported (8).

On the basis of our results, we conclude that of the two pathogens studied, E. coli $\mathrm{O} 157: \mathrm{H} 7$ is better able to

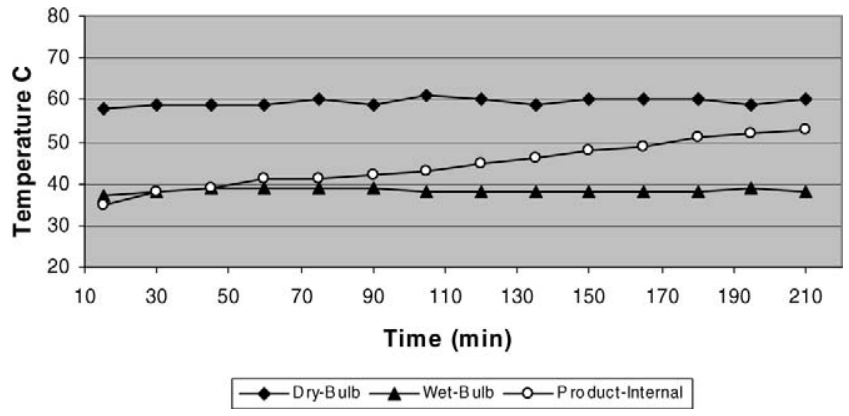

FIGURE 3. Wet-bulb, dry-bulb, and product internal temperatures during the manufacture of whole-muscle beef jerky using a type 5 process with a dry-bulb temperature setting of $60.0^{\circ} \mathrm{C}$ $\left(140^{\circ} \mathrm{F}\right)$. survive the heating and drying steps used in making wholemuscle beef jerky. However, foodborne illness outbreaks linked to beef jerky have primarily involved Salmonella serovars, so it is prudent for any validation of a jerky-making process to involve both pathogens. Because our results clearly show the importance of wet-bulb temperature or percent RH in achieving mandated lethality, we strongly

TABLE 6. Comparison of whole-muscle beef jerky processing lethality against Salmonella serovars $(S)$, Escherichia coli O157:H7 $(E C)$, and Pediococcus acidilactici $(P A)$

\begin{tabular}{|c|c|c|c|c|c|}
\hline \multirow[b]{2}{*}{ Process type } & \multicolumn{3}{|c|}{$\begin{array}{l}\text { Lethality for } \\
\text { finished sample }{ }^{a}\end{array}$} & \multicolumn{2}{|c|}{$\begin{array}{l}\text { PA counts } \\
\text { (log CFU) }\end{array}$} \\
\hline & $S$ & $\mathrm{EC}$ & PA & Initial & Final \\
\hline Consumer & 4.4 & 2.8 & 2.6 & 4.3 & 1.7 \\
\hline Consumer & 4.2 & 3.0 & 1.8 & 4.3 & 2.5 \\
\hline 1-B: $87.8^{\circ} \mathrm{C}$ dry-bulb temp & 7.0 & 7.4 & 3.2 & 4.5 & 1.3 \\
\hline 1-B: $87.8^{\circ} \mathrm{C}$ dry-bulb temp & 7.2 & 7.1 & $>3.2$ & 4.2 & $0.95^{b}$ \\
\hline 1-B: $65.5^{\circ} \mathrm{C}$ dry-bulb temp & 6.7 & 7.1 & 3.2 & 4.7 & 1.5 \\
\hline 1-B: $65.5^{\circ} \mathrm{C}$ dry-bulb temp & 6.9 & 6.9 & 2.8 & 3.8 & 1.0 \\
\hline 1-A: spices only & 7.1 & 7.1 & $>3.2$ & 4.2 & 0.95 \\
\hline 1-A: spices only & 6.6 & 7.1 & $>2.7$ & 3.7 & 0.95 \\
\hline 1-A: water only & 6.6 & 6.9 & $>2.6$ & 3.6 & 0.95 \\
\hline 1-A: water only & 6.1 & 7.0 & 3.0 & 4.5 & 1.5 \\
\hline 2 & 6.4 & 6.4 & $>3.3$ & 4.3 & 0.95 \\
\hline 2 & 6.1 & 5.6 & $>2.3$ & 3.3 & 0.95 \\
\hline 3 & 5.5 & 5.6 & 3.2 & 4.5 & 1.3 \\
\hline 4 & 4.7 & 5.4 & 2.9 & 4.2 & 1.3 \\
\hline 4 & 5.8 & 5.0 & 3.2 & 4.2 & 1.0 \\
\hline 4 & 5.8 & 6.7 & 2.8 & 3.8 & 1.0 \\
\hline 4 & 4.7 & 5.4 & 3.2 & 4.2 & 1.0 \\
\hline 4 & 5.6 & 5.9 & $>3.4$ & 4.4 & 0.95 \\
\hline 5 & 3.8 & 3.9 & 1.9 & 4.0 & 2.1 \\
\hline 7 & 6.0 & 5.6 & 2.6 & 3.6 & 1.0 \\
\hline
\end{tabular}

${ }^{a}$ Reduction in $\log$ CFU per sample relative to initial pathogen load before marination. Values are the mean of three samples for $\mathrm{S}$ and $\mathrm{EC}$ and the mean of two samples for PA.

${ }^{b} \mathrm{~A}$ value of 0.95 was assigned when no surviving cells were detected. 
recommend that processors buy or make a wet-bulb thermometer for use in processing or use a hygrometer to monitor humidity and then use a commercially available slide rule to determine wet-bulb temperature from known drybulb temperatures and percent $\mathrm{RH}$ values.

Reductions in counts of Salmonella serovars and $E$. coli $0157: \mathrm{H} 7$ of $\geq 5.0 \log \mathrm{CFU}$ can be achieved in the production of whole-muscle beef jerky by ensuring that wet-bulb temperatures and percent $\mathrm{RH}$ values are high enough and are reached and maintained early in the process or that high dry-bulb temperature heating and drying occurs before the beef strip water activity has fallen below 0.86 . Alternatively, guidelines from the USDA (14) indicate that internal temperatures listed in Appendix A for time and temperature combinations (13) are effectively wet-bulb temperatures. Processors could consider a process valid when early in the process the chamber wet-bulb temperature and therefore the product internal temperature reaches or exceeds a designated level for at least as long as is specified in Appendix A.

\section{ACKNOWLEDGMENTS}

The authors gratefully acknowledge the laboratory assistance of Ryan Algino, Greg Burnham, Rebecca Engel, Melody Fanslau, Amy Haen, Erica Ready, Erica Schoeller, and Melissa Talbot and the smokehouse assistance of Ruben Zarraga. This work was supported by a grant from the U.S. Department of Agriculture, Food Safety and Inspection Service.

\section{REFERENCES}

1. Blankenship, L. C. 1978. Survival of Salmonella typhimurium experimental contaminant during cooking of beef roasts. Appl. Environ. Microbiol. 35:1160-1165.

2. Blankenship, L. C., C. E. Davis, and G. J. Magner. 1980. Cooking methods for elimination of Salmonella typhimurium experimental surface contaminant from rare dry-roasted beef roasts. J. Food Sci. 45:270-273.

3. Eidson, M., C. M. Sewell, G. Graves, and R. Olson. 2000. Beef jerky gastroenteritis outbreaks. J. Environ. Health 62:9-13.
4. Englejohn, D. (U.S. Department of Agriculture, Food Safety and Inspection Service). 2005. Personal communication.

5. Goepfert, J. M., I. K. Iskander, and C. H. Amundson. 1970. Relation of the heat resistance of salmonellae to the water activity of the environment. Appl. Microbiol. 19:429-433.

6. Goodfellow, S. J., and W. L. Brown. 1978. Fate of Salmonella inoculated into beef for cooking. J. Food Prot. 41:598-605.

7. Harrison, J. A., M. A. Harrison, R. A. Rose-Morrow, and R. L. Shewfelt. 2001. Home-style beef jerky: effect of four preparation methods on consumer acceptability and pathogen inactivation. $J$. Food Prot. 64:1194-1198

8. Holley, R. A., A. M. Lammerding, and F. Tittiger. 1988. Occurrence and significance of streptococci in fermented Italian type dry sausage. Int. J. Food Microbiol. 7:63-72.

9. Nummer, B. A., J. A. Harrison, M. A. Harrison, P. Kendall, J. N. Sofos, and E. L. Andress. 2004. Effects of preparation methods on the microbiological safety of home-dried meat jerky. J. Food Prot. 67:2337-2341.

10. Potter, N. N. 1978. Food science, 3rd ed. AVI Publishing Company, Inc., Westport, Conn.

11. ProMED-mail. 2003. Salmonella Kiambu, beef jerky-USA (New Mexico). Archive no. 20031001.2471. International Society for Infectious Diseases. Available at: http://www.promedmail.org. Accessed 21 July 2005.

12. Uhler, P. (U.S. Department of Agriculture, Food Safety and Inspection Service). 2005. Personal communication.

13. U.S. Department of Agriculture, Food Safety and Inspection Service. 1999. Compliance guidelines for meeting lethality performance standards for certain meat and poultry products, appendix A. Available at: http://www.fsis.usda.gov/oa/fr/95033f-a.htm. Accessed 24 May 2005.

14. U.S. Department of Agriculture, Food Safety and Inspection Service. 2004. Compliance guideline for meat and poultry jerky produced by small and very small plants. Available at: http://www.fsis.usda.gov/ PDF/Compliance_Guideline_Jerky.pdf. Accessed 4 May 2005.

15. U.S. Department of Agriculture, Food Safety and Inspection Service. 2005. Food standards and labeling policy book. Available at: http:// www.fsis.usda.gov/OPPDE/larc/Policies/Labeling_Policy_Book_082005. pdf. Accessed 11 November 2005.

16. U.S. Department of Agriculture, Food Safety and Inspection Service. 2005. Risk assessment of the impact of lethality standards on salmonellosis from ready-to-eat meat and poultry products; draft for public review and comment. Available at: http://www.fsis.usda.gov/ PDF/Risk_Assessment_RTE_Salm_Leth_Main.pdf. Accessed 21 July 2005. 